University for Business and Technology in Kosovo

UBT Knowledge Center

UBT International Conference

2015 UBT International Conference

Nov 7th, 9:00 AM - 5:00 PM

\title{
Energy production in Kosova and regional perspectives
}

Ardian B. Gojani

University for Business and Technology, ardian.gojani@ubt-uni.net

Follow this and additional works at: https://knowledgecenter.ubt-uni.net/conference

Part of the Engineering Commons

\section{Recommended Citation}

Gojani, Ardian B., "Energy production in Kosova and regional perspectives" (2015). UBT International Conference. 45.

https://knowledgecenter.ubt-uni.net/conference/2015/all-events/45

This Event is brought to you for free and open access by the Publication and Journals at UBT Knowledge Center. It has been accepted for inclusion in UBT International Conference by an authorized administrator of UBT Knowledge Center. For more information, please contact knowledge.center@ubt-uni.net. 


\title{
Energy production in Kosova and regional perspectives
}

\author{
Ardian B. Gojani \\ UBT - Higher Education Institution \\ ardian.gojani@ubt-uni.net
}

\begin{abstract}
This paper presents and analy ses the current state of the energy sector in Kosova. It assesses the potential for development, and investigates the needs of the sector. Kosova's energy sector is in a dire state presenting an obstacle for economic development of the country. The sector is not compliant with international standards and codes and has negative consequences for both system operators and consumers. In addition, this paper presents a general overview of energy production and use in the region, and discusses the possibility for coalescence. In conclusion, the report presents a few possible scenarios for the development of the energy sector.
\end{abstract}

Keywords: Kosovo Energy Sector, Energy Production, Energy Sector Development

\section{Introduction}

Energy sector ${ }^{1}$ has been and remains one of the pillars of Kosovan economy. Out of several potential primary energy sources, Kosova has extensively relied on large lignite reserves for its energy needs. Nevertheless, this sector has been performing poorly for a long time, which correlates with the overall poor national economy.

The establishment of energy sector, similarly to most of Kosova's industry, took place during the socialist times (i.e., between 1960s and 1980s). This includes the establishment of Kosova's thermal power plants and mining. The legacy of this era can still be observed in several points, such as the vertical integration of Kosova Energy Corporation (KEK) [1]. The unbundling of KEK into specialized companies is an ongoing process, as it has already happened with the energy distribution part and the establishment of KESCO and KEDS.

The poor management of this sector is reflected in the lack of secure and reliable energy and in the uncertainty of future developments. Although the improvements in electricity supply as compared to a decade ago are obvious ${ }^{2}$, Kosova's energy sector does not operate in a sustainable manner. As an illustration serves the fact that electricity is one of the top five exported and imported products, but the overall net balance is negative, as shown in table 1 .

Most of Western Balkan countries are net importers of energy (Bosnia and Herzegovina is the only exception, while Serbia and Montenegro occasionally are self-sufficient). The dominant primary energy in the region is coal, which participates with $73 \%$ of the total electricity production, followed by hydropower (14\%), and gas and petroleum products (13\%), as given in table 2 .

Table 1. Electricity trade exchange (in euro) [2]

\begin{tabular}{ccc}
\hline & 2013 & 2014 \\
\hline Import & $28,447,948$ & $45,823,382$ \\
Export & $21,820,972$ & $16,028,771$ \\
\hline
\end{tabular}

\footnotetext{
${ }^{1}$ For the purposes of this paper, energy sector refers to all relevant actors in the electrical power production, management and consumption. This excludes the transport (oil) industry.

2 The infamous power reductions (load sheddings) accordingto zones A, B and C, which would have 4,3 and 2 hours of power in a six hour time frame, do not exist anymore.
} 
International Conference on Energy Efficiency Engineering, Nov 2015

Table 2. Share of electricity supply (2014) [3]

\begin{tabular}{cccccc}
\hline Country & $\begin{array}{c}\text { Capacity } \\
(\mathrm{GW})\end{array}$ & $\begin{array}{c}\text { Consumption } \\
(\mathrm{TWh})\end{array}$ & Thermal & $\begin{array}{c}\text { Hydro \& } \\
\text { RES }\end{array}$ & Import \\
\hline Albania & 1.8 & 7.8 & $1 \%$ & $57 \%$ & $42 \%$ \\
Bosnia and H. & 4.0 & 12.2 & $43 \%$ & $57 \%$ & $-20 \%$ \\
Kosova & 1.2 & 5.4 & $79 \%$ & $1 \%$ & $20 \%$ \\
Macedonia & 2.0 & 5.0 & $66 \%$ & $33 \%$ & $37 \%$ \\
Montenegro & 0.8 & 3.3 & $20 \%$ & $72 \%$ & $8 \%$ \\
Serbia & 7.0 & 34.0 & $56 \%$ & $38 \%$ & $6 \%$ \\
\hline
\end{tabular}

\section{Primary energy sources}

Energy production in Kosova is overwhelmingly reliant in exploitation of coal, as is illustrated in table 3, which shows the overall energy sources for the country. There are a few functioning hy dropower plants, but their total electricity production does not exceed $3 \%$ of the overall production in the country. Firewood is an important component to the energy balance, because most of the energy consumption in Kosova is for space and water heating in households. With regards to natural gas, Kosova does not have resources nor a pipeline based transmission system. Fuel oil is imported and is used mainly for transport with an average of 1.5 million liters per day. The potential of renewable sources is moderate at best. Kosova has adopted the feed-in-tariff mechanisms for supporting investments in the renewable energy sources.

The fragility of the energy system can be observed by noting that the imported electricity in 2014 increased drastically due to the explosion in one of the power plant units ${ }^{3}$.

Table 3. Available primary sources of energy (in ktoe)

\begin{tabular}{lrrr}
\hline & 2012 & 2013 & 2014 \\
\hline Coal & $1,528.10$ & $1,521.60$ & $1,524.30$ \\
Oil (imported) & 560.65 & 579.32 & 606.87 \\
Biomass & 247.49 & 247.65 & 251.60 \\
Electric energy (imported) & 13.09 & -28.82 & 48.74 \\
Hydropower & 8.20 & 12.32 & 11.04 \\
Solar & 0.69 & 0.76 & 0.53 \\
& & & $2,443.28$ \\
\hline
\end{tabular}

\subsection{Lignite}

Lignite exploitations initiated in 1922, but large scale works commenced in 1958, when the Mirash mines opened, and continued with the opening of the Bardh mine in 1969. These were open-pit mines with bucket wheel excavators. Cumulative extraction for the first 82 years of exploitation (1922-2004) amounts to $265 \mathrm{Mt}$ ( $1 \mathrm{MT}=1,000,000$ tonnes). The deposits average $40 \mathrm{~m}$ thickness, with a 1.7:1 strip ratio. Estimated lignite reserves in Kosova amount to more than 10,000 Mt [4], which puts Kosova in the top twenty countries in the world in terms of absolute coal reserves [5]. Current annual exploitation does not exceed $8 \mathrm{Mt}$, which means that fuel reserves are not an issue for any plans regarding construction of new thermal power plants (TPP).

Coal is of lignite type (there are no anthracite and bituminous types of coal in Kosova), thus it has low energy density. But, other chemical, physical and extraction parameters are very favorable. Coal quality values are [6]

$>$ Moisture content: $35--50 \%$

$>$ Ash contents: $12--21 \%$

$>$ Heating values: $7.8--8.1 \mathrm{MJ} / \mathrm{kg}$

3 In June 6, 2014, the electroly sis unit of the TPP Kosova A5 exploded, causing death to two workers, injuries to fourteen and considerable material damages. The explosion is thought to have occurred due to the leak of hydrogen, but there are no conclusive reports. 
$>$ Sulfur: $<1 \%$

$>$ Relative heating values:

\author{
$>8.4 \mathrm{MJ} / \mathrm{kg}: 29 \%$
}

7.7-8.4 MJ/kg: $43 \%$

5.8-7.7 MJ/kg: $25 \%$

Lime concentration is sufficient to absorb significant amount of SOX during combustion, so that desulfurization of flue gases is not required.

Thus, although heat value (energy density) of Kosova's lignite is quite poor, its relatively low sulfur content is an advantage, in particular for environmental considerations. Another advantage is the easy access to coal: lignite is mined in open-pit mines with an extremely good overburden to ore ratio $(1.7: 1)$.

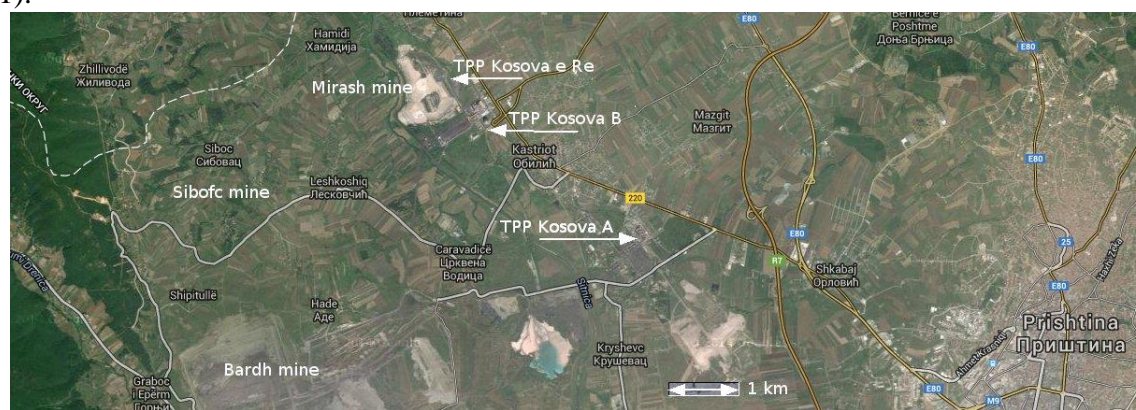

Figure 1. A map of thermal power plants and mines in Kosova. North-western part of Prishtina is visible in the lower-right corner of the figure. (Prepared with Google Maps.)

Table 4. Thermal power plants in Kosova

\begin{tabular}{lrrrr}
\hline Unit & Installed (MW) & Net (MW) & Min-Max(MW) & Commissioned \\
\hline A1 & 80 & 65 & NONOP & 1962 \\
A2 & 150 & 125 & NONOP & 1965 \\
A3 & 200 & 180 & $100-130$ & 1970 \\
A4 & 200 & 180 & $100-130$ & 1971 \\
A5 & 210 & 187 & RR & 1975 \\
B1 & 339 & 310 & $180-260$ & 1983 \\
B2 & 339 & 310 & $180-260$ & 1984 \\
\hline
\end{tabular}

\title{
2.2 Thermal power plants
}

There are two thermal power plants in Kosova -- for their installed and operational capacities, as well as the commissioning date, see table 4. Both are located in Kastriot, $15 \mathrm{~km}$ from Prishtina, as shown in figure 1. In the vicinity of the plants are the Mirash and Bardh mines, but they are nearing coal exhaustion. Since 2010, coal is also mined in the New Mine Field (Sibofc South-West), and a large mine in Sibofc i Madh is also under development. Both plants operate with a plant efficiency of about $25-30 \%$, while modern plants operate at over $40 \%$ efficiency. During the past fifteen years, TPP Kosova A has seen considerable investments, including placement of filters. On TPP Kosova B on the other hand, no large interventions have happened since the commissioning of the plant more than 30 years ago.

TPP Kosova A. Installed capacity of TPP Kosova A, which consisted of five units, was $800 \mathrm{MW}$. Now two units are not operational any more, and one unit (A5) is being repaired and it is expected to return to production soon. At the present, TPP Kosova A produces about $200 \mathrm{MW}$. Currently, units $\mathrm{A} 1$ and $\mathrm{A} 2$ are non-operational (NONOP), while unit A5 is under repair (RR). In operational mode, unit A5 has a Min-Max value of $135 \mathrm{MW}$.

TPP Kosova A has been put for decommissioning, with the condition that the Kosova e Re project would proceed smoothly. The initial proposed date for decommissioning was 2017, but it is very unlikely that this will happen, because the construction of Kosova e Re would take at least six years. Instead, supporting facilities (e.g. gasification and fertilizer) will be decommissioned. These facilities are already non-functional. In recent announcements, the decommissioning of TPP Kosova A is linked to the initial production from the Kosova e Re, thus the time line of these two plans are interlocked. 
There exist a proposal by Bilfinger company that suggests a stepwise reconstruction by installing one FDG (flue-gas desulfurization) plant from Babcock for A1 and A2, and another one for A3, A4, and A5 units. In addition, TPP Kosova A will be equipped with E-filters, boilers, turbine and DCS from Siemens. The revitalization of plant would make it operational for about 30 more years. The entire cost is estimated at around $800-1,000$ million euro.

TPP Kosova B. Installed capacity of TPP Kosova B, which consists of two units, was $678 \mathrm{MW}$. The boilers, turbines and generat ors of these units were produced by Stain Industries, M AN, and Alsthrom, respectively. TPP Kosova B continuously has had mechanical and electrical problems, in particular damages to turbine rotors, which caused frequent termination of operation. The net capacity of the plant is about $500 \mathrm{MW}$. An unspecified rehabilitation of both units is proposed in all national energy strategy documents, but no concrete plans exist yet. Revitalization of TPP Kosova B would include boilers and placement of filters, in a total cost of about 300-400 million euro. Since the plant is with the same facilities as when it started operation 30 years ago, it is not compliant with the EU Directive on Large Combustion Plant and emission of gases, but this can be remedied with modern filters. An initial estimation is that the revitalization of the plant would increase its service years for another 1520 years.

A novel development is the adaptation of unit B2 for district heating by cogeneration, a project that has successfully passed the initial stage of operation.

New lignite plant Kosova e Re. The lignite-based thermal power plant project Kosova e Re was initiated more than ten years ago. The initial projected production was $2,100 \mathrm{MW}$, but due to political changes in 2007, the project went through a reviewing process and the projected production was downgraded to $1,000 \mathrm{MW}$. In 2009, just after the Copenhagen Conference, the project was halted and went through a new reviewing process. The outcome of the second review was that the projected production was downgraded again, now to $600 \mathrm{MW}(2 \times 300)$. But, it was also decided that a new mine in Sibof with $830 \mathrm{Mt}$ of lignite should be opened, independently of the Kosova e Re project.

Kosova e Re is intended to be developed in compliance with all European standards and directives, with the installation of the best available technologies such as pulverized coal (PC) and circulating fluidized bed (CFB), which ensure that environment pollution is minimal, and with an efficiency of at least $37 \%$. The realization of this project will ensure replacement of electricity generation from TPP Kosova A, coverage of domestic electricity consumption demand, environmental improvements in the energy sector, and provision of security of electricity supply.

It is estimated that the plant will use about $5.5 \mathrm{Mt}$ lignite annually. This is to be secured by the new Sibofc mine, which would be an extension of the Sibofc South-West mine and which is not operational yet. In fact, discussions on expropriation of the land are going on currently. While the plant will be in private ownership, the mining license remains with KEK. For the time being, it is uncertain under what conditions the new plant will be supplied with lignite.

Table 5. Operational hydropower plants in Kosova

\begin{tabular}{lrrrr}
\hline Plant & Installed (MW) & Net (MW) & Commissioned & Renewed \\
\hline Ujmani & 35.00 & 32.00 & 1983 & \\
Lumbardhi & 8.80 & 8.00 & 1957 & 2006 \\
Dikanci & 1.00 & 0.94 & 1957 & 2010 \\
Radaci & 0.90 & 0.84 & 1937 & 2010 \\
Burimi & 0.86 & 0.80 & 1948 & 2011 \\
\hline
\end{tabular}

\subsection{Renewable energy sources}

Country energy strategies have continuously been developed with the emphasis on coal as the main energy source will be coal, while the utilization of renewable energy sources (RES) was left to the private sector. A number of studies show that Kosova has a substantial potential to generate up to 800 MW by using renewable sources [7,8]. This capacity is large enough to justify investments in this sector, and as a beneficiary consequence will be the diversification of the energy sources, 
subsequently improving security of supply. Nevertheless, the expectation that RES will provide a good opportunity for new jobs in Kosova has been too optimistic ${ }^{4}$.

Biomass. Biomass in the form of firewood is already being used for heating individual homes. Kosova is $44 \%$ forests and the current use of biomass is just in balance to the forest regeneration [9]. There are project proposals for utilizing wood and agricultural waste for power generation, mainly for district heating.

Water. A prefeasibility study conducted in 2006 estimated that Kosova has an annual hydro-energy potential of about $700 \mathrm{GWh}$, with the envisioned HPP Zhur covering half of this amount [10]. Currently Kosova has installed capacity of about $45 \mathrm{MW}$ from four hy dropower plants, given in table 5. Apart from Ujmani, which is managed by the Hydro-Economic Enterprise Iber-Lepenci, all other plants are privately owned.

The plans for the construction of HPP Zhur with generating capacity of $305 \mathrm{MW}$ and production of around $400 \mathrm{GWh} / \mathrm{y}$ ear have been put forward, but the project has stalled since 2012 and can be considered as failed, although new feasibility study of this project within the next years might be initiated. The main obstacle for the realization of this project was the disagreement between the governments of Albania and Kosova on sharing river/water resources. Now, many families have build homes in the area where the water reservoir was supposed to be constructed, thus reconsidering this project incurred additional costs.

Wind. Studies on Kosova's potential for electricity generation by wind power vary considerably. Three wind turbines are already placed in Golesh by a private investor, with total capacity of less than 1.4 MW. Their operation is experiencing considerable difficulties, some of which stem for the disagreements between the investor and ERO on wind energy tariff. Overall, wind energy contribution to the energy market is negligible.

Kosova does not have a wind atlas, while desktop studies do not show sufficient wind speeds for substantial power generation, and the most optimistic estimation for wind capacity is that 140-300 MW can be produced by 2025 .

Solar. Solar radiation in Kosova is estimated to be between 1,000 and $1,600 \mathrm{kWh} / \mathrm{m} 2$ per year [11], which can be utilized either indirectly (as heat for passive heating of buildings or as solar thermal panels equipped with antifreeze), or directly (electricity production by means of photovoltaics). There are a few cases of solar energy utilization, but these are mainly individual investments with extremely limited input in the overall energy exchange. A recent proposal for an up to $3 \mathrm{MW}$ solar park sufficient for supplying about 1,200 families with electricity has been put forward. In any case, the solar energy is seen as a small to medium contributor (up to $80 \mathrm{MW}$ ) and costly.

\section{Electricity infras tructure}

Due to its central position in the South-East European region, Kosova's transmission sy stem serves as a major hub in the regional energy market. Kosova has a good transmission system (see table 6) and is connected to all neighboring countries with $400 \mathrm{kV}$ lines, with the exception of Albania ${ }^{5}$. There are plans for an additional $110 \mathrm{kV}$ transmission line between these two countries and and a $400 \mathrm{kV}$ line between Kosova and Macedonia.

The maximum capacity of energy exchange between Kosova and neighboring countries is about 1,740 MW. The new line connecting Kosova and Albania will add 500 MW to this capacity. A similar

4 According to report from EBRD, in ten years of investments from this bank in this sector, only 893 new working places have been opened.

5 But, the construction of this line is nearing its completion. This line is expected to be finished by the end of 2016 . 
capacity will be added with the construction of the line between Kosova and Macedonia. With regards to the age of the lines, $72 \%$ of $400 \mathrm{kV}$ and $60 \%$ of $110 \mathrm{kV}$ lines are older than 35 years, while the majority of $220 \mathrm{kV}$ lines (77\%) are between 25 and 35 years old.

Currently, Kosova Transmission, System and Market Operator(KOSTT) does not intend investments in the $220 \mathrm{kV}$ lines, but only in 400 and $110 \mathrm{kV}$ ones. Transmission and distribution losses were always a major source of concern. Transmission losses are small (less than $2 \%$ of total electricity consumption) and are reduced continuously. Distribution losses, on the other hand, remain large. Although billing and payment of the electricity has improved (up to $91 \%$ in 2012 compared to $60 \%$ in 2006), still a large amount of energy is lost due to technical (16\% in 2012) and nontechnical causes (20\% in 2012).

Apart from KOSTT and the Albanian transmission operator OST, all national transmission systems of the Western Balkan countries are members of the ENTSO-E [12].

Table 6. Electricity transmission lines in Kosova

\begin{tabular}{lrr}
\hline Voltage $(\mathrm{kV})$ & Number of lines & Length $(\mathrm{km})$ \\
\hline 400 & 6 & 182 \\
220 & 13 & 232 \\
110 & 45 & 728 \\
\hline
\end{tabular}

\section{Energy efficiency}

Several studies consider energy efficiency (EE) a more important topic to consider in Kosova's context, instead of renewable sources. Kosova needs to strengthen the legal framework and implementation mechanisms to meet its own 9\% target for energy efficiency improvement by 2018 [13]. Since 2010, several projects have started to introduce energy efficiency measures in public buildings both at central and municipal level. The main obstacles to implementing energy efficiency measures in Kosova have been the lack of capital required for investment measures, lack of incentives from the government and high interest rates at commercial banks; low level of awareness regarding insulation cost-effectiveness; and lack of implementing standards in building construction and materials supply.

A number of actions are planned for saving energy in all stages, including production (efficient lignite extraction, increase of conversion efficiency of power plants, etc.), transmission (improvement of grid, reduction of technical and commercial losses, etc.), and consumption. Several municipalities have put forward EE projects that focus on insulation measures of public buildings. In particular, over 60 schools have already been retrofitted so as to serve as demonstration projects for EE. It is expected that the energy saved by improved insulation of buildings by the year 2018 would be up to 100 ktoe. Only three municipalities in Kosova (Prishtina, Gjakova and Mitrovica) have district heating (DH), and only Prishtina's one is currently operational. Even during their full operational state, these supplied only $5 \%$ of the heating demand. A recent development has been the adoption of Prishtina's $\mathrm{DH}$ into a CHP/cogeneration (combined heating and power) system, which takes steam from TPP Kosova B Unit 2. First estimates show that cogeneration uses $80 \mathrm{MW}$ power, but in return it saves 8 $\mathrm{MW}$ of electricity use.

\section{Environmental impact}

Air quality monitoring in Kosova is a legal obligation, but the existing infrastructure is modest with respect to the number of monitoring stations (eight in total) and monitoring parameters (particulate matter PM10 and PM2.5, SO2, NO2, O3 and CO2). Air monitoring is conducted by all main single point source contributors to air pollution in Kosova, which are KEK, NewCo Ferronikeli (located in Drenas, $40 \mathrm{~km}$ west of Prishtina), SharrCem (located in Hani i Elezit, $30 \mathrm{~km}$ south of Prishtina), and Trepca. All large plants must be equipped with the Integrated Permit, which is issued in accordance to the Integration Pollution Prevention Control directive. Currently, Sharrcem and Ferronikeli possess these permits, while KEK's is under processing. Considering the fact that on average a liter of oil is 
spent by a Kosovan per day, transport might be among the largest polluters, nevertheless, there are no specific measurements of air pollution from this sector.

The latest report on the state of the environment was published in 2013, which covers the monitoring done during the period 2011-2012 [14]. Since in the mean time energy production did not increase significantly, by interpolation the current state may be considered similar. The findings are that PM 10 and PM2.5 values exceed maximum allowed values by many orders. In this regard, particulate matter is the most serious pollutant in the country. Levels of greenhouse gases and toxic gas emissions are exceeded, but to a more manageable level. In any case, emissions from KEK exceed allowed levels for all monitored parameters, while SharrCem and Ferronikeli claim that the emissions from their activities are within allowed limits.

\section{Energy economy}

Energy market in Kosova is dominated by oil (imported 100\%), which is mainly used for transport ${ }^{6}$ and electricity (home product and imported). Two other energy sources in use in Kosova are firewood (home product) and gas (imported 100\%), but these are either used seasonally (firewood for heating in winter) or in modest amounts (gas for cooking). Compared to countries in the Balkan region, the cost of electricity consumption (euro per $\mathrm{kWh}$ ) in Kosova is cheaper than in Albania, Bosnia and Herzegovina and Montenegro, but it is more expensive than in Serbia and Macedonia. Compared to the EU average, Kosovans pay less in absolute terms, but more in relative terms (when GDP, purchasing power and other economic parameters are taken into account) [15]. In 2013, about 60\% of households in Kosova spent on average $20 \%$ of their incomes in electricity bills [16].

\subsection{Energy consumption}

The main energy users are households, followed by transport, industry, services and agriculture, as shown in table 7. This is another reflection of the poor economic state of the country ${ }^{7}$.

Table 7. Energy consumption by sector (ktoe) [17]

\begin{tabular}{lrrrr}
\hline & 2012 & 2013 & 2014 & \\
\hline Households & 473.73 & 495.52 & 517.98 & $41 \%$ \\
Transport & 342.65 & 328.52 & 332.24 & $25 \%$ \\
Industry & 272.98 & 266.63 & 282.35 & $22 \%$ \\
Services & 117.09 & 118.79 & 116.34 & $10 \%$ \\
Agriculture & 19.85 & 29.34 & 29.85 & $2 \%$ \\
\hline
\end{tabular}

Although electricity is one of the major components of energy, an increasing number of households with an increased frequency use cheaper alternatives: gas for cooking and firewood for space heating. Electricity remains the main source for water heating, lighting and home appliances. Firewoods constitute a considerable energy source for heating space in winter. On average, a household uses about $10 \mathrm{~m} 3$ of wood per season, at the cost of about 250-500 euro. Since a substantial part of electricity is used for heating, consumption varies substantially with seasons, and is susceptible to

6 Occasionally, oil is used for electricity production in KEK as well.

7 As a comparison to a period when industrial production in Kosova was substantial - during the 1980s, the ratio of energy consumption between industry and households was 3:1. 
weather conditions. As an illustration might serve the fact that there was an overall decrease in consumption in 2013 and 2014 as compared to previous years, because of milder winters.

Electricity losses. Electricity inflow in transmission system is of the order of $8,000 \mathrm{GWh}$, of which about $110 \mathrm{GWh}$ are lost (less than 1.5\%). This value is still larger than the allowed limit by ERO, namely $0.78 \%$. Drastic losses in electricity take place during distribution. These losses are divided into technical losses, which appear in the distribution network components (power line cables, transformation stations, substations, etc), and commercial losses, which refer to the misuse of electricity. Technical losses have continuously accounted for about $17 \%$ of losses, while commercial losses have had a steady but slow decrease from $25 \%$ in 2008 to $20 \%$ in 2012. Thus, the current overall electricity loss in distribution is at over $35 \%$. It is expected that the distribution losses for the current year (2015) will amount to $1,275 \mathrm{GWh}$ (27\% of the total distribution needs).

\subsection{Eectricity demand}

The demand for electricity has been in continuous increase, with an average $7 \%$ increase during the period 2000-2010. This period has seen doubling of the electricity demand from about $2.8 \mathrm{TWh}(241$ ktoe) to $5.7 \mathrm{TWh}$ (490 ktoe). Since then, demand has flattened. It must be noted that there are no significant generation capacities built during this period. Long term balance of energy envisions a continued increase of electricity consumption [18]. Energy consumption for Kosova is given in the figure 2 , with the estimated consumption for the following years.

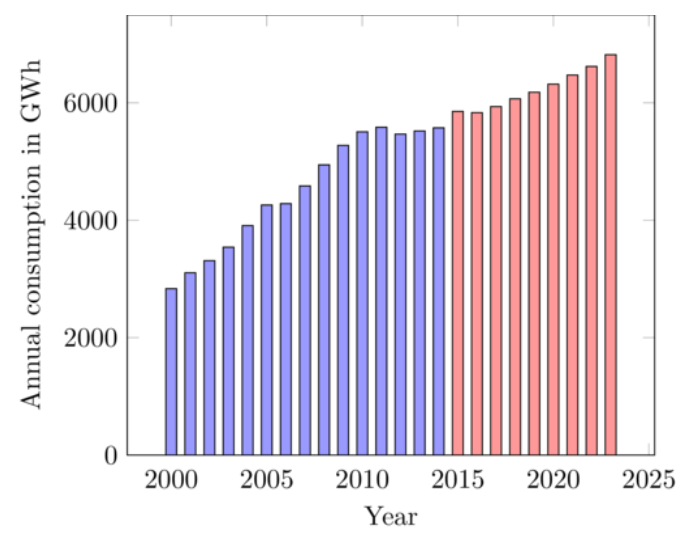

Figure 2. Energy consumption and estimated demand for Kosova.

It is envisioned that this demand will come mainly from the household and industry consumption, while a substantial decrease of distribution losses in absolute terms is not expected. This electricity demand would be supplied by electricity generation in TPP Kosova B and Kosova e Re and renewables (hy dropower and wind plants). The current electricity import levels of over $600 \mathrm{GWh}$ will be reduced to $100 \mathrm{GWh}$ within the next two years and would cease completely by 2021 .

Regional market. The region has seen a continuous increase of electricity demand during the past fifteen years, while the supply is not sufficient to fulfill these needs. Hence, the region remains a net electricity importer. While Albania is making improvements and it has reached a level when it produces more electricity than it imports, Macedonia has witnessed increased levels of electricity imports. Montenegro electricity demand is volatile, because the operation of a single factory (Aluminum Plant Podgorica) equaled the entire electricity demand of the nation. Bosnia and Herzegovina is the only net exporter of electricity, while Serbia exports electricity occasionally. All countries have plans for improving their energy infrastructure by developing new thermal and hydroplants. Nevertheless, there is plenty of room for optimization of energy resources, under the condition that a closer integration of the region takes place. 
Demand variations. Electricity consumption during summer and winter seasons varies enormously, reaching even increase of $150 \%$ the amount of electricity needs. Obviously, this is caused by the extensive use of electricity for household heating in winter. A firm annual base load is estimated to be around $500+/-150 \mathrm{MW}$, with a seasonal base load variation over this value up to $400 \mathrm{MW}$. Peak variations, though, reach almost equal values, namely up to 300-400 MW. Seasonal variation of peak loads for the past years is given in the figure 3 .

The most intensive demand of electricity in a daily time frame is between the periods 9:00 and 12:00 and 17:00-23:00. In these cases, the load reaches up to $400 \mathrm{MW}$ (around 40\%) of the average demand ${ }^{8}$. Summer and winter peak demands in a daily schedule coincide.

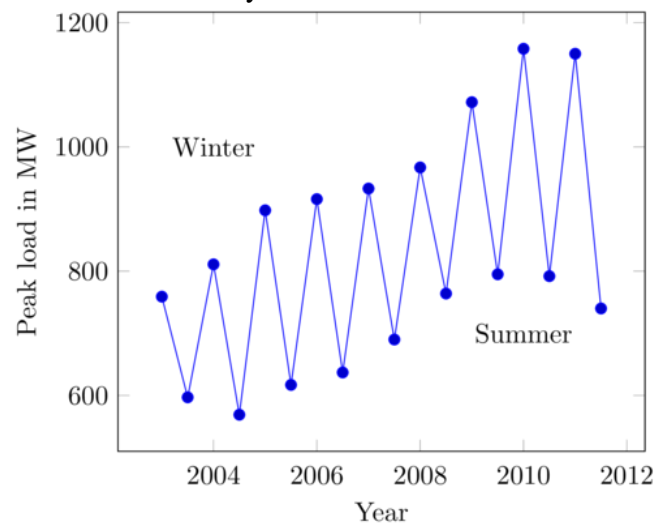

Figure 3. Seasonal variation of peak load during summer (lower dots) and winter (higher dots).

\section{Future outlook and conclusion}

There exist several scenarios that predict the future development of the Kosovan energy sector, but one constant is that, in Kosova's context, coal is indispensable, at least for the next several decades. Considering the dismal condition of the existing TPPs, investments in their repair and revitalization or in construction of new TPP are necessary. Not necessarily mutually exempting scenario is the one that includes the revitalisation of TPP Kosova A and the commission of Kosova e Re.

TPPs are facilities suited for supplying the base load. Kosova, on the other hand, does not posses any facility for electricity storage. If HPP Zhur would have proceeded, this would be a great opportunity not only for providing a renewable source, but also a source that could have been used for peak load. Another op portunity exists in the joint electricity market between Kosova and Albania. In terms of electricity production, both countries are complementary and Kosova's TPP and Albania's HPP can be adjusted according to base and peak demands. On the other hand, regulation of the market is still undecided: there can be a single regulatory body serving the entire market, or a joint operation by regulatory offices of each country can work in unison. These and other issues are yet to be determined.

Kosova has rightly emphasized energy efficiency as one of the main points to be considered by the energy sector. But, unlike current energy efficiency efforts at the energy consumption end, more emphasis could be placed in the energy production part.

Establishment of a joint Kosova-Albania energy market is the first step in developing an energy sector beneficial to both countries, with possibilities for expansion of regional collaboration. Lignite remains the most important fuel for the region and most energy policies center around efficient use of this resource.

8 Maximal demand is between 19:00 and 21:00 and minimal between 4:00 and 6:00. 


\section{References}

1. International Energy Agency, Energy in the Western Balkans: the Path to Reform and Reconstruction, 2008.

http://www.iea.org/publications/freepublications/publication/balkans2008.pdf

2. Ministry of Trade and Industry, Trade Exhanges 2014, 2015. http://www.mti-

ks.org/repository/docs/Tradel_Exchanges \2014\_578997.pdf

3. Energy Community Secretariat, Annual Implementation Report 2014, 2015.

https://www.energy -

community.org/portal/page/portal/ENC\_HOME/DOCS/3872267/EnC \_IR2015WEB.pdf

4. Ministry of Economic Development, Mining strategy of the Republic of Kosovo 2012-2025, 2012.

http://www.kuvendikosoves.org/common/docs/Strategiia \Minerarel_el_R.I_Kosoves $\_2012 \backslash$ $-\backslash \_225\lfloor\backslash$ Ang.pdf

5. H. Andruleit et al., Reserves, Resources and Availability of Energy Resources, 2013. http://www.bgr.bund.de/EN/Themen/Energie/Downloads/energiestudiel_2013 _en.pdf

6. Invest KS, Lignite mining development strategy, 2010. http://www.invest-

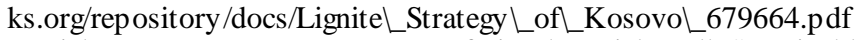

7. Daniel M. Kammen, Mary am Mozafari and Daniel Prull, Sustainable Energy Options for Kosova: An analy sis of resource availability and cost, University of California, Berkeley, 2012. http://coolclimate.berkeley .edu/sites/all/files/Kosova20May2012.pdf

8. GIZ, Renewable energy as an Opportunity for Economic Development in Kosova, 2012. http://www.nek.ch/windenergie-geothermie-e/publikationen/dokumente/ 2013.05.30\GIZ\_Study\english \final\_16012013.pdf

9. S. M. Tomter, et al., Kosovo National Forestry Inventory 2012, Ministry of Agriculture, Forestry and Rural Development, 2013. http://www.mbpzhr-

ks.net/repository/docs/84090\Inventarizimi-Nacional-i-Pyjeve-Kosov1\%EB-2012\_web.pdf

10. AAEESD, Preafisibility study for identification of water resources and their utilization through small hydro power plant on Kosova, 2006.

http://dkfvg.progetti.informest.it/extranet/RID/FCKeditor/File/13-115-280307-151622.pdf

11. N. Avdiu and A. Hamiti, Renewable Energy Policy and Market Developments in Kosova, ICREPQ11, 2011. http://www.icrepq.com/icrepq1\%2711/527-avdiu.pdf

12. https://www.entsoe.eu/

13. Ministry of Economic Development, Second National Energy Efficiency Action Plan, 2013. http://mzhe.rks-gov.net/repository/docs/Kosovo\_2nd\_NEEAP $\_-$ $\left\lfloor\right.$ FINAL\_draft $\_2013\lfloor E N G(5)$.pdf

14. Kosovo Environment Protection Agency, Report on the State of Environment 2011-2012, 2013. http://www.ammk-rks.net/repository/docs/Web\_anglisht.pdf

15. KOSID, Cmimi i energjise elektrike, 2013. http://www.kosid.org/file/repository/2305\CmimiEnergiiseELektrike.pdf

16. B. H. Bowen et al., Kosova household energy consumption, 2013. https://www.rit.edu/research/cenr/sites/rit.edu.research.cenr/files/2013\_03\_01\_cenr _Kosova $\left\lfloor\right.$ household \energy $\_$consumption.pdf

17. Kosovo Agency of Statistics, Annual Energy Balance in the Republic of Kosovo for 2014, 2015. https://ask.rks-gov.net/ENG/energy/publications/docl_download/1318-annual-energybalance-in-the-republic-of-kosovo-for-2014-

18. Ministry of Economic Development, Long-term energy balance of the Republic of Kosovo 2015-2024, 2014. http://www.mzhe-ks.net/repository/docs/Long-

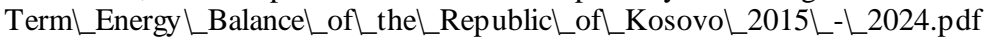

